\title{
The Role of Information Technology on Teaching Process in Education; An Analytical Prospective Study at University of Sulaimani
}

\author{
Mohammad Esmail Ahmad ${ }^{1}$ \\ Computer Engineering Department, College of Engineering, \\ Komar University of Science and Technology \\ Sulaimani, Iraq \\ Statistics and Informatics Department, College of \\ Administration and Economics, University of Sulaimani. \\ Sulaimani, Iraq \\ Ameer Sardar K. Rashid ${ }^{2}$ \\ Marketing Management Department, College of \\ Administration and Economics, University of Sulaimani \\ Sulaimani, Iraq
}

\author{
Amanj Anwar Abdullah ${ }^{3}$ \\ Accounting Department, College of Administration and \\ Economics, University of Sulaimani. \\ Sulaimani, Iraq
}

\author{
Raza M. Abdulla ${ }^{4}$ \\ Statistics and Computer Department, College of Commerce, \\ University of Sulaimani \\ Sulaimani, Iraq
}

\begin{abstract}
Nowadays Information Technology (IT) has been engaged in all spheres of life. It plays an important role in developing and processing works in all types of organizations, especially in the teaching process in institutions and universities. The purpose of this paper is to present the impact of information technology in the process of learning progress and teaching improvement in the University of Sulaimani from both lecturers and students perspective view, also to determine the common key factors which teaching process relies upon the information technology framework. In this paper, the researchers created an online questionnaire survey and took a sample number of academic staff and students in different colleges and departments of the University of Sulaimani in 2017, which were 320 questionnaires. The paper shows that information technology has become a basic need not dispense within the teaching process in universities and institutions in this era, also emphasize that various level of understanding of Information Technology serves various learning and teaching process.
\end{abstract}

Keywords-Information and communication technology; education; evaluation of information technology

\section{INTRODUCTION}

Technology is a procedure, which includes a composite of human interactions, community, cultural factors, and technical domains. Technology is generally used in many fields as an electronic tool such as the calculator, television, and the computer. Therefore, they consist of multiple functions [1]. "The usage of information technology (IT), broadly referring to computers and peripheral equipment, has seen tremendous growth in service industries in the recent past." [2]. Information Technology (IT) is the field, which is growing recently. IT used to design, progress, apply, organize and admin an information system in computer especially software application, and a physical element. The computer software which transform, calculate, stock, rescue, procedure, transfer, select, collect, secure, and obtain the information [3]. Information technology consists of computers, wired, wirelesses, networks, data and Information, system and devices, all of these today offer an essential infrastructure which activates through facts of community. Learning and teaching are depended on Information technology [4].

\section{INFORMATION AND COMMUNICATION TECHNOLOGY (ICT)}

ICT stands for Information and Communication technologies, there are many definitions of ICT such as "diverse set of technological tools and resources used to communicate, to create, to disseminate, to store, and to manage information" [10]. ICTs are making dynamic changes in education. They are influencing all the aspects of education. The influences are felt more and more at schools and colleges. Because ICT provides both students and teachers with more opportunities in adapting learning and teaching to individual needs. Tinio (2002), states the potentials of ICT in increasing access and improving relevance and quality of education in developing countries. The potentials of ICT greatly facilitate the acquisition and absorption of knowledge in education with low cost. ICT plays a vital role in preparing quality policy [6].

The employment of ICT explained by youthful writers in their illustrations uncovers a universal nearness of person to person communication stages as relics officially coordinated into the collection of assets they use for learning [16].

Information and Communication Technology (ICT) has turned into a world apparatus frequently utilized by people, associations, governments, and intergovernmental associations for individual or authority exercises. Its application cut over all fields of a human undertaking like pharmaceutical, trade, building, engineering, training, library administrations, and agribusiness[17]. 


\section{A. Importance of Information Technology (IT)} [5]:

The Importance of (IT) can be summarized as the following

1) Information Technology works on major changes in the entire organization, as in their products, markets, and gives employees the flexibility to work anywhere either in their organizations or at home.

2) Provide more information to assist in controlling the decisions taken by their users.

3) Help to create new communication channels, therefore, it increases flowing and processing the exchange of information and develop modern management methods.

4) Works to improve and increase business opportunities between organizations, and between organizations and the government, which led to a wider spread of information.

5) Helps to detect deviations to prevent the aggravation and works on a specialized processor.

6) Help to improve customer service by meeting their demands via terminals.

7) Improves the quality of work through the adoption of new technological methods and thus achieve high accuracy, shorten the time, reduce costs and risk of humanitarian unprepared interpretation of the information and data.

8) Contributes to reduce the volume of the costs, which is allocated to provide factors of production.

9) Improves the process of collecting, processing, storing, retrieving, updating and reducing the cost of data, as it would reduce the cost of administrative work.

10)Create the most effective managerial tools to apply what can be applied in the normal conditions and leading the renewal process.

\section{B. Component of Information Technology (IT)}

Information technology consists of the following five parts, as shown in Fig. 1, [11]:

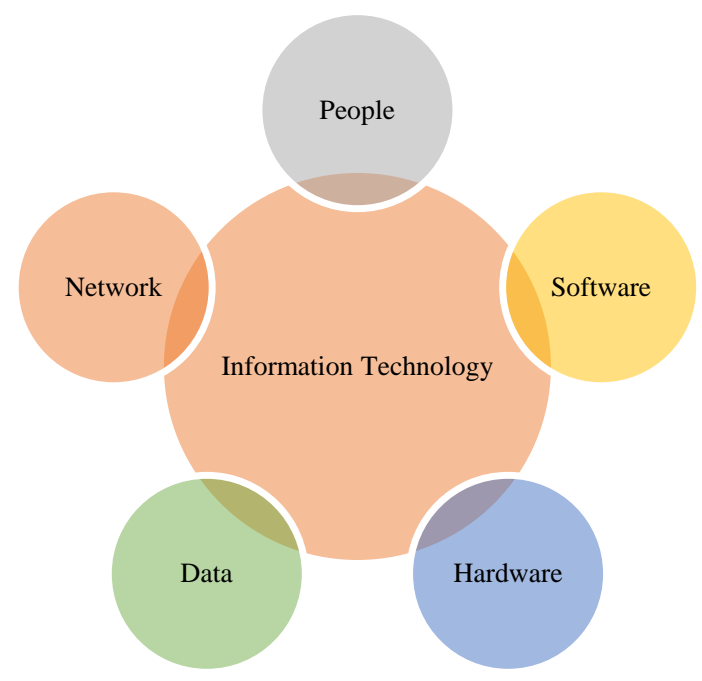

Fig. 1. Component of Information Technology.
1) People resources: the people who use, progress, and operate information technology.

2) Hardware resources: Refers to physical devices such as computers and networks tools.

3) Software resources: both of the programs and procedures which consist of a collection of instruction to execute and accomplish a specific task.

4) Data resources: refers to a sum of facts like text, numbers, images, sounds, and knowledge base to accommodate the knowledge in different ways such as facts and rules.

5) Network resources: Refer to communications media, and network support, that include wire cable, people, hardware, software, and data.

\section{ICT Framework}

There are many ways of ICT framework:

Access: Combine or/and return information from the sources that might be database, websites, online or media.

Manage: arrange, organize, sort, and categorize the information and documents with ease to retrieve them when needed.

Integrate: using digital tools to assemble, synopsis, and compare information from different sources, as well as illustrate and explain information.

Create: organize information, design, implement, and create in digital environments.

Communicate: sharing documents, email, and penetration to a specific audience [7].

\section{EDUCATION}

One of the most important active factors that make an influence in many aspects of an education system is Information and Communication Technology (ICT), which is strongly felt in universities because it provides suitable tools and techniques for both teachers and students to adapt the teaching and learning process. In developing countries, the effect of ICT, more likely, increases and improves the quality of education. The power of ICT strongly helps to gain broader knowledge in the education system with a low cost, so the quality policy relies on ICT [10]. Education is strongly related to the community and the quality of education accessed with teachers which had perfect characteristics that connect with learners. Recently the ICT is a cornerstone which helps to facilitate the process of learning in order to arrive enormous amount of information. Also, it has the ability to rise, improve, and enhance the knowledge and capabilities of students anytime from anywhere in the educational environment [14]. ICT is considered as a robust tool which can support the instructors to send the information in verity forms. It also motivates all instructors to use the technologies to driven and solve the problems, analyze the information, and to share the ideas and resources during the process of teaching in the learner institute [15]. 


\section{A. Information Technology as Methods and Purpose of Education}

Information Technology provides opportunities for selections and plans for education. The spread of information technology is seen virtual in education, which everyone can obtain, by a website, or internet technology. Information Technology (IT) can directly be sent into anywhere that is necessary. Education is directly impacted by information technology. Thus, technology connected, systematized, saved, and transferred. As a purpose, information technology has influenced to change the targets of education, because education is the process of build, save, convey, and implement of knowledge [9].

\section{B. ICTs in Secondary Education}

In the past few years, ICT rises not only in the university education system but also in the secondary education system. Thus, students are more familiar with the tools and the potentials of ICT and how to use it for the benefit of their learning process. While students enrolled in universities, they are having a clear idea of ICT in the education system and what it can do for them. However, still, this process in Kurdistan of Iraqi universities is under developing process. The adult generation transfers installation process, evaluation process and their experiences to the younger generation based on what they have already been developed so that the younger generation improve it [12].

\section{ICTs and Quality of Education}

Successful and powerful society is related to the quality of the education of the individuals and accordingly to the society as a whole. In such a society, the individuals may possess some ability like [12]:

1) Being up-to-date with all recent ideas in the field of science and technology.

2) Obtaining the latest technology skills.

3) Individuals educating themselves widely.

The products of quality educations which is known as selfsupporting and knowledge of science and technology have to supply an effective participation of an individual in progressing societies. The process of improving the quality of education can be recognized based on some suitable conditions that prove the objectives of education, like [12]:

1) Lecture halls have to be well equipped.

2) Administrators in managerial positions have to be highly professional.

3) Teaching staff and technical members should be highly qualified.

4) High-quality textbooks and professional literature should be available and easily accessible for both students and teaching staffs.

\section{ICT in and for Education}

The process of successful teaching and learning can rely on technology filled with both goal and dread. The goal can be reached to the higher level of learner compared with what they have learned in the past, while dread is the base which is needed to spread resources of technology or build an influent
ICT interface, which has a flaw in low-income countries. In this case, the ICT can be distributed into two parts; first is ICT for Education and second is ICT in Education. ICT for education lead to evolving information and communication especially for teaching/learning objectives, while ICT in Education includes the procedure of training of instructors to use a technology during the process of teaching [8]

\section{E. Curriculum and Teacher Development}

Both students and teachers required to be up-to-date with curriculums and suitable teacher development for keeping on the track in technological development. A sophisticated ICT Curriculum is required to be implemented by teachers, and any newly developed curriculum required accurate managerial preparation and availability of resources and support [13].

\section{DATA COLLECTION}

The questionnaire was made available at the beginning of the academic year 2017. The survey was distributed online by emailing a convenient sampling of 167 academics and 160 students with the URL to the survey at the University of Sulaimani in six (6) faculties. The survey included six sections for both instructors and students. The questions comprised many aspects, which related to information technology such as personal information, information technology, internet line, college, study inside the university, also instructors and students' opinions, which related to the information technology and influence on the processing of teaching.

\section{A. Question about General Information-Instructors Part}

Table (I) illustrates information about the general information of participated instructors. The percentage of gender participation in the survey was $(35 \%)$ male and $(64 \%)$ female. Approximately (42\%) of the respondents aged 34 to 43 and $(33 \%)$ were aged 24 to 33 while (19\%) were aged 44 to 53 . The maximum number of respondents are assistant lecturers by (50\%) while the lowest respondents were from professors, which was $(3 \%)$.

TABLE I. INSTRUCTORS SAMPLE DEMOGRAPHICS

\begin{tabular}{|l|l|l|}
\hline Section I: Personal Information & $\%$ \\
\hline \multirow{4}{*}{ Variables } & Characteristics & $35 \%$ \\
\hline \multirow{5}{*}{ Age } & Male & $65 \%$ \\
\cline { 2 - 3 } & Female & $33 \%$ \\
\hline \multirow{5}{*}{ Scientific Level } & 24 to 33 years & $42 \%$ \\
\cline { 2 - 3 } & 34 to 43 years & $19 \%$ \\
\cline { 2 - 3 } & 44 to 53 years & $5 \%$ \\
\cline { 2 - 3 } & 54 to 63 years & $1 \%$ \\
\cline { 2 - 3 } & 64 years and above & $50 \%$ \\
\hline & Assistant Lecturer & $30 \%$ \\
\cline { 2 - 3 } & Lecturer & $3 \%$ \\
\cline { 2 - 3 } & Assistant Professor & \\
\cline { 2 - 3 } & Professor & \\
\hline
\end{tabular}


TABLE II. INFORMATION TECHNOLOGY DEMOGRAPHICS

\begin{tabular}{|l|l|l|}
\hline Section 2 : Information Technology & \multicolumn{2}{|l|}{} \\
\hline Variables & Characteristics & $\%$ \\
\hline \multirow{3}{*}{$\begin{array}{l}\text { Which electronic devices do you } \\
\text { use? }\end{array}$} & Mobile & $39 \%$ \\
\cline { 2 - 3 } & Tablet & $9 \%$ \\
\cline { 2 - 3 } & Laptop & $40 \%$ \\
\cline { 2 - 3 } & Desktop & $12 \%$ \\
\hline \multirow{3}{*}{$\begin{array}{l}\text { Which operating system do you use } \\
\text { on your computer? }\end{array}$} & Windows & $83 \%$ \\
\cline { 2 - 3 } & Mac & $14 \%$ \\
\cline { 2 - 3 } & Linux & $3 \%$ \\
\hline \multirow{4}{*}{$\begin{array}{l}\text { How many hours ydo ou spend on } \\
\text { using a computer systen? }\end{array}$} & $0-1$ & $13 \%$ \\
\cline { 2 - 3 } & $1-3$ & $40 \%$ \\
\cline { 2 - 3 } & $3-6$ & $36 \%$ \\
\cline { 2 - 3 } & $6-10$ & $10 \%$ \\
\cline { 2 - 3 } & More than 10 Hours & $3 \%$ \\
\hline \multirow{2}{*}{ Do you use the internet at home? } & Yes & $99 \%$ \\
\cline { 2 - 3 } & No & \\
\hline
\end{tabular}

TABLE III. ABOUT INTERNET DEMOGRAPHICS

\begin{tabular}{|c|c|c|}
\hline \multicolumn{3}{|l|}{ Section 3: About Internet Line } \\
\hline Variables & Characteristics & $\%$ \\
\hline \multirow{12}{*}{$\begin{array}{l}\text { Which type of internet line do you } \\
\text { use? }\end{array}$} & IQ & $8 \%$ \\
\hline & Groan net & $45 \%$ \\
\hline & Fast Line & $10 \%$ \\
\hline & Fast Link & $14 \%$ \\
\hline & Tish net & $3 \%$ \\
\hline & Asia Cell & $11 \%$ \\
\hline & Fanoos Telecom & $4 \%$ \\
\hline & Korak & $1 \%$ \\
\hline & Next net & $1 \%$ \\
\hline & Brusk net & $1 \%$ \\
\hline & All Sard & $1 \%$ \\
\hline & Zain & $1 \%$ \\
\hline \multirow{2}{*}{$\begin{array}{l}\text { What type of internet access and } \\
\text { supplier do you use? }\end{array}$} & Wire & $15 \%$ \\
\hline & Wireless & $85 \%$ \\
\hline \multirow{8}{*}{ How fast is your internet speed? } & Below $256 \mathrm{Kbps}$ & $6 \%$ \\
\hline & $256-512 \mathrm{Kbps}$ & $28 \%$ \\
\hline & 512-1 Mbps & $19 \%$ \\
\hline & 1-2 Mbps & $8 \%$ \\
\hline & 2-4 Mbps & $7 \%$ \\
\hline & 4-8 Mbps & $13 \%$ \\
\hline & 8-24 Mbps & $10 \%$ \\
\hline & Above $24 \mathrm{Mbps}$ & $9 \%$ \\
\hline \multirow{5}{*}{$\begin{array}{l}\text { How many e-mail addresses do } \\
\text { you have? }\end{array}$} & 1 & $5 \%$ \\
\hline & 2 & $46 \%$ \\
\hline & 3 & $28 \%$ \\
\hline & 4 & $11 \%$ \\
\hline & More than 4 & $10 \%$ \\
\hline
\end{tabular}

Table (II) shows information about section (2) which consists of four questions (Q1, Q2, Q3, and Q4). Question 1 illustrates information about the electronic devices that are utilized by instructors. Most of them preferred Laptop, which was (40\%) while (9\%) used Tablet. The second question explains the type of operating system that is used by instructors. The majority of instructors utilized Windows Operating system, which was $(83 \%)$ whereas the minimum number of them used Linux system, which was (3\%). The third question of this section related to the time that spent in order to use a computer which was (40\%) of instructors spent (1-3) hours while just only (3\%) spent more than 10 hours. The final question determines information about the internet used at home, the largest percentage used the internet at home was $(99 \%)$.

Table (III) illustrates information about section (3) which includes four questions (Q5, Q6, Q7, and Q8). Question 5 gives information about the type of internet line that is used by instructors. The majority of instructors relied on Goran net line which was $(45 \%)$ while the minority of them utilized Korak, Brusk net, All Sard and Zain respectively which were (1\%). Question 6 explains the type of internet supply, which is used to receive internet access. Most of the instructors preferred wireless which was $(85 \%)$ but only $(15 \%)$ of them used wire connection. Question 7 focused on the speed of the internet line by Kbps. (28\%) of instructors had internet line with speed 256$512 \mathrm{Kbps}$, however, $(6 \%)$ of them obtained below $256 \mathrm{Kbps}$. The last question in table talks about the number of email addresses which were used by instructors. In general, (46\%) of the instructors had two email addresses while (5\%) owned one email address.

TABLE IV. ABOUT COLLEGE DEMOGRAPHICS

\begin{tabular}{|c|c|c|}
\hline \multicolumn{3}{|l|}{ Section 4: About College } \\
\hline Variables & Characteristics & $\%$ \\
\hline \multirow{3}{*}{$\begin{array}{l}\text { Which of these technologies } \\
\text { do you use in your college? }\end{array}$} & $\begin{array}{l}\text { Computer and Data } \\
\text { Show }\end{array}$ & $98 \%$ \\
\hline & Smart board & $1 \%$ \\
\hline & Specific Program & $1 \%$ \\
\hline \multirow{2}{*}{$\begin{array}{l}\text { Is there any computer in the } \\
\text { teaching halls (except lab } \\
\text { Computer) available? }\end{array}$} & Yes & $17 \%$ \\
\hline & No & $83 \%$ \\
\hline \multirow{2}{*}{$\begin{array}{l}\text { Do you have a university } \\
\text { profile? }\end{array}$} & Yes & $90 \%$ \\
\hline & No & $10 \%$ \\
\hline \multirow{3}{*}{$\begin{array}{l}\text { Does your university have an } \\
\text { activity in international } \\
\text { magazines? }\end{array}$} & Yes & $45 \%$ \\
\hline & Little & $39 \%$ \\
\hline & No & $16 \%$ \\
\hline \multirow{5}{*}{$\begin{array}{l}\text { How many electronic devices } \\
\text { do you use to obtain internet } \\
\text { services inside the } \\
\text { university? }\end{array}$} & 0 & $25 \%$ \\
\hline & 1 & $51 \%$ \\
\hline & 2 & $21 \%$ \\
\hline & 3 & $2 \%$ \\
\hline & More than 3 & $1 \%$ \\
\hline \multirow{2}{*}{$\begin{array}{l}\text { Does your library have } \\
\text { internet line? }\end{array}$} & Yes & $41 \%$ \\
\hline & No & $59 \%$ \\
\hline
\end{tabular}

Table (IV) shows information about section (4) which contains six questions (Q9, Q10, Q11, Q12, Q13, and Q14). Question 9 provides information about the kind of technology that utilized during the process of teaching by instructors. (98\%) preferred to use computer and data show were compared with the smart board and specific program which were (1\%) respectively. Question 10 shows the fact that teaching halls are not equipped with computers. The next question describes the university profile that owned by instructors. (90\%) of the instructors had made university profile whereas (10\%) does not. Question 12 in this section points out the university activities in world magazines. The greater number of answers was $(45 \%)$, which believed that university does not have any activity in international magazines while (16\%) of them thinks reversely. Question 13 shows the number of electronic devices which are utilized inside the university in order to obtain internet services. Most of the instructors used one electronic 
device, which was (51\%); however, (1\%) utilized more than three devices. The final question provides information about internet services in the library, (59\%) are not aware of the internet services but (41\%) of them are aware of the existing of internet services.

Table (V) illustrates information about section (5) which comprises of five questions (Q15, Q16, Q17, Q18, and Q19). Question 15 shows (64\%) of the instructors preferred courses in soft copy while (36\%) of them preferred courses in hard copy. Next question shows (\%79) of the instructors allow their students to use a different kind of technologies in their classes and sessions, while $(21 \%)$ of them restricting their students to use any kind of technology. Question 17 related to question 16 which focused on the allowance of use technology in all the instructor sessions, $(85 \%)$ of them allowed on all their session, while $(15 \%)$ only allowed on computer sessions. Question 18 determined the existing of a special computer in labs, (70\%) of labs in six faculties don't have special computers for their courses but $(30 \%)$ of labs have special computers. The last question asked about the knowledge of instructors about IT, (54\%) believe they have a good knowledge and experience of IT, while (46\%) think they don't have any experience and knowledge.

TABLE V. STUDY INSIDE UNIVERSITY DEMOGRAPHICS

\begin{tabular}{|l|l|l|}
\hline Section 5: Study Inside University \\
\hline Variables & Characteristics & $\mathbf{\%}$ \\
\hline \multirow{2}{*}{$\begin{array}{l}\text { In which way you prefer } \\
\text { course materials? }\end{array}$} & Soft copy & $64 \%$ \\
\cline { 2 - 3 } & Hard Copy & $36 \%$ \\
\hline $\begin{array}{l}\text { During the teaching, do you } \\
\text { allow to use technology in } \\
\text { your session? }\end{array}$ & Yes & $79 \%$ \\
\cline { 2 - 3 } & No & $21 \%$ \\
\hline $\begin{array}{l}\text { If your answer (Yes) in the } \\
\text { above question, for which } \\
\text { session of the course do you } \\
\text { allow? }\end{array}$ & $\begin{array}{l}\text { Just computer } \\
\text { session }\end{array}$ & $15 \%$ \\
\hline $\begin{array}{l}\text { In the computer labs, do you } \\
\text { have a special computer? }\end{array}$ & Yes & $30 \%$ \\
\cline { 2 - 3 } $\begin{array}{l}\text { Do you have the experience to } \\
\text { use Information Technology } \\
\text { (IT)? }\end{array}$ & Yes & $70 \%$ \\
\cline { 2 - 3 } & No & $54 \%$ \\
\hline
\end{tabular}

\section{B. Question about General Information-Students Part}

TABLE VI. STUDENTS SAMPLE DEMOGRAPHICS

\begin{tabular}{|l|l|l|}
\hline Section 1: Personal Information & Characteristics & \% \\
\hline Variables & Male & $50 \%$ \\
\hline \multirow{4}{*}{ Gender } & Female & $50 \%$ \\
\hline \multirow{4}{*}{ Age } & Less than 20 years & $20 \%$ \\
\cline { 2 - 3 } & 21 to 25 years & $72 \%$ \\
\cline { 2 - 3 } & Over 25 years & $8 \%$ \\
\hline \multirow{5}{*}{ Class } & First & $11 \%$ \\
\cline { 2 - 3 } & Second & $20 \%$ \\
\cline { 2 - 3 } & Third & $39 \%$ \\
\cline { 2 - 3 } & Forth & $27 \%$ \\
\cline { 2 - 3 } & Fifth & $2 \%$ \\
\cline { 2 - 3 } & Sixth & $1 \%$ \\
\hline
\end{tabular}

Table (VI) illustrates information about the general information of participated students. The percentage of gender participation in the survey was $(50 \%)$ male and $(50 \%)$ female. Approximately, $(72 \%)$ of the respondents, aged 21 to 25 and (20\%) were aged less than 20 while $(8 \%)$ were aged over 25 years. The largest respondents rate $(39 \%)$ were from the third class while the smallest respondents rate $(2 \%)$ and $(1 \%)$ were from fifth and sixth classes respectively.

TABLE VII. INFORMATION TECHNOLOGY DEMOGRAPHICS

\begin{tabular}{|c|c|c|}
\hline \multicolumn{3}{|l|}{ Section 2 : Information Technology } \\
\hline Variables & Characteristics & $\%$ \\
\hline \multirow{4}{*}{$\begin{array}{l}\text { Which electronic devices do you } \\
\text { use? }\end{array}$} & Mobile & $67 \%$ \\
\hline & Tablet & $3 \%$ \\
\hline & Laptop & $18 \%$ \\
\hline & Desktop & $12 \%$ \\
\hline \multirow{3}{*}{$\begin{array}{l}\text { Which operating system do you } \\
\text { use on your computer? }\end{array}$} & Windows & $95 \%$ \\
\hline & Mac & $4 \%$ \\
\hline & Linux & $1 \%$ \\
\hline \multirow{5}{*}{$\begin{array}{l}\text { How many hours do you use a } \\
\text { computer on average? }\end{array}$} & $0-1$ & $60 \%$ \\
\hline & $1-3$ & $19 \%$ \\
\hline & $3-6$ & $11 \%$ \\
\hline & $6-10$ & $7 \%$ \\
\hline & $\begin{array}{l}\text { More than } 10 \\
\text { Hours }\end{array}$ & $3 \%$ \\
\hline \multirow{2}{*}{ Do you use internet line at home? } & Yes & $96 \%$ \\
\hline & No & $4 \%$ \\
\hline
\end{tabular}

Table (VII) shows information about section (2) which consists of questions (Q1, Q2, Q3, and Q4) the question 1 illustrates information about the electronic devices that utilized by students. Most of them preferred mobile which was $(67 \%)$ while (3\%) used tablets. The second question explains the type of operating systems that are used by students. The majority of students utilized the Windows operation system, which was (95\%) whereas the minimum number of them used Linux system, which was $(1 \%)$. The third question in this section related to the time that spent in order to use a computer which was $(60 \%)$ of students spent (1-3) hours while just only $(3 \%)$ spent more than 10 hours. The final question determines information about the internet line used at home, The largest percentage used the internet at home was (96\%).

Table (VIII) illustrates information about section (3) which includes four questions (Q5, Q6, Q7, and Q8). Question 5 gives information about the type of internet service that is used by students. The majority relied on Goran net which was (33\%) while the minority who utilized Brusk net and Zain respectively which were (1\%). Question 6 explains the kinds of service used to receive internet access. Most of the students preferred wireless which was $(90 \%)$ but only $(15 \%)$ of them used wire connection. Question 7 focused on the speed of the internet line by Kbps. (30\%) of students had internet line with speed 256-512 Kbps, however (4\%) obtained it above 24 Mbps. The last question in this table asks about the number of email addresses used by students. In general, the largest ratio of students had one email address, which was (58\%) while (1\%) owned more than 4 email addresses. 
TABLE VIII. ABOUT INTERNET DEMOGRAPHICS

\begin{tabular}{|c|c|c|}
\hline \multicolumn{3}{|l|}{ Section 3: About Internet } \\
\hline Variables & Characteristics & $\%$ \\
\hline \multirow{11}{*}{$\begin{array}{l}\text { Which type of internet service } \\
\text { do you use? }\end{array}$} & IQ & $5 \%$ \\
\hline & Groan net & $33 \%$ \\
\hline & Fast Line & $13 \%$ \\
\hline & Fast Link & $11 \%$ \\
\hline & Tish net & $17 \%$ \\
\hline & Asia Cell & $6 \%$ \\
\hline & Fanoos Telecom & $3 \%$ \\
\hline & Korak & $8 \%$ \\
\hline & Max net & $2 \%$ \\
\hline & Brusk net & $1 \%$ \\
\hline & Zain & $1 \%$ \\
\hline \multirow{2}{*}{$\begin{array}{l}\text { Which type of service do you } \\
\text { use to receive the internet? }\end{array}$} & Wire & $10 \%$ \\
\hline & Wireless & $90 \%$ \\
\hline \multirow{8}{*}{$\begin{array}{l}\text { How fast is your internet } \\
\text { speed? }\end{array}$} & Below $256 \mathrm{Kbps}$ & $12 \%$ \\
\hline & 256-512 Kbps & $30 \%$ \\
\hline & 512-1 Mbps & $16 \%$ \\
\hline & $1-2$ Mbps & $13 \%$ \\
\hline & 2-4 Mbps & $13 \%$ \\
\hline & 4-8 Mbps & $7 \%$ \\
\hline & $8-24 \mathrm{Mbps}$ & $5 \%$ \\
\hline & Above 24 Mbps & $4 \%$ \\
\hline \multirow{6}{*}{$\begin{array}{l}\text { How many E-mail addresses do } \\
\text { you have? }\end{array}$} & 0 & $11 \%$ \\
\hline & 1 & $58 \%$ \\
\hline & 2 & $26 \%$ \\
\hline & 3 & $2 \%$ \\
\hline & 4 & $2 \%$ \\
\hline & More than 4 & $1 \%$ \\
\hline
\end{tabular}

TABLE IX. ABOUT COLLEGE DEMOGRAPHICS

\begin{tabular}{|c|c|c|}
\hline \multicolumn{3}{|l|}{ Section 4: About College } \\
\hline Variables & Characteristics & $\%$ \\
\hline \multirow{3}{*}{$\begin{array}{l}\text { Which of these technologies do } \\
\text { you use in your college? }\end{array}$} & $\begin{array}{l}\text { Computer and Data } \\
\text { Show }\end{array}$ & $94 \%$ \\
\hline & Smart board & $3 \%$ \\
\hline & Specific Program & $3 \%$ \\
\hline \multirow{2}{*}{$\begin{array}{l}\text { Is there any computer in teaching } \\
\text { hall (except lab Computer)? }\end{array}$} & Yes & $23 \%$ \\
\hline & No & $77 \%$ \\
\hline \multirow{2}{*}{ Do you have a university profile? } & Yes & $21 \%$ \\
\hline & No & $79 \%$ \\
\hline \multirow{2}{*}{$\begin{array}{l}\text { Does your university have an } \\
\text { activity in international } \\
\text { magazines? }\end{array}$} & Yes & $37 \%$ \\
\hline & No & $63 \%$ \\
\hline \multirow{5}{*}{$\begin{array}{l}\text { How many electronic devices do } \\
\text { you use to obtain internet } \\
\text { services inside the university? }\end{array}$} & 0 & $24 \%$ \\
\hline & 1 & $60 \%$ \\
\hline & 2 & $13 \%$ \\
\hline & 3 & $1 \%$ \\
\hline & More than 3 & $2 \%$ \\
\hline \multirow{2}{*}{$\begin{array}{l}\text { Does your library have internet } \\
\text { line? }\end{array}$} & Yes & $45 \%$ \\
\hline & No & $55 \%$ \\
\hline
\end{tabular}

The table (IX) shows information about section (4) which contains six questions (Q9, Q10, Q11, Q12, Q13, and Q14). Question 9 provides information about the kind of technology that utilized during the process of learning by Students. The (94\%) of the students preferred their instructors to use computer and data show were compared with the smart board and specific program which were (3\%) respectively. Question
10 shows the fact that teaching halls are not equipped with computers. The next question describes the university profile that owned by students. (21\%) of the students think they may have a university profile which is not, whereas (79\%) does not thinks they don't have it. Question 12 in this section points out the university activities in world magazines. The greater number of answers was (63\%), which believed that university does not involve in any activity in international magazines while (37\%) of them thinks reversely. Question 13 shows the number of electronic devices which are utilized inside the university in order to obtain internet services. Most of the students used one electronic device, which was (60\%); however, (1\%) utilized three devices. The final question provides information about the internet services in the library, $(55 \%)$ are not aware of the internet services but $(45 \%)$ of them are aware of the existing of internet services.

TABLE X. STUDY INSIDE UNIVERSITY DEMOGRAPHICS

\begin{tabular}{|l|l|l|}
\hline Section 5: Study Inside University & Characteristics & $\mathbf{\%}$ \\
\hline Variables & Soft copy & $46 \%$ \\
\cline { 2 - 3 } $\begin{array}{l}\text { In which way you prefer course } \\
\text { materials? }\end{array}$ & Hard Copy & $54 \%$ \\
\hline $\begin{array}{l}\text { During the learning, are you } \\
\text { been allowed to use technology } \\
\text { in your classes? }\end{array}$ & Yes & $42 \%$ \\
\cline { 2 - 3 } & No & $58 \%$ \\
\hline $\begin{array}{l}\text { If your answer (Yes) in the } \\
\text { above question, for which } \\
\text { session of the course you'd been } \\
\text { allowed? }\end{array}$ & $\begin{array}{l}\text { Just computer } \\
\text { session }\end{array}$ & $76 \%$ \\
\cline { 2 - 3 } $\begin{array}{l}\text { To what extent you rely on a } \\
\text { computer when you are doing a } \\
\text { homework? }\end{array}$ & All homework & $8 \%$ \\
\cline { 2 - 3 } & Some homework & $62 \%$ \\
\cline { 2 - 3 } & I don't need it & $30 \%$ \\
\hline $\begin{array}{l}\text { In the computer labs, do you } \\
\text { have a special computer? }\end{array}$ & Yes & $50 \%$ \\
\cline { 2 - 3 } $\begin{array}{l}\text { Do you have the experience to } \\
\text { use Information Technology } \\
\text { (IT)? }\end{array}$ & Yes & $50 \%$ \\
\cline { 2 - 3 } & No & $21 \%$ \\
\hline
\end{tabular}

Table (X) shows information about section (5) which comprises of six questions (Q15, Q16, Q17, Q18, Q19, and Q20). Question 15 shows (46\%) of the students preferred courses in soft copy while (54\%) of them preferred courses in hard copy. Next question shows (\%42) of the students had been allowed by their instructors to use a different kind of technologies in their classes and sessions, while (58\%) of them don't have a chance to use it. Question 17 related to question 16 which focused on the allowance of use technology in all the student classes, only (24\%) of them allowed on all their session, while (76\%) only allowed on computer labs. Question 18 gives an idea about the dependency of students for doing their homework, (62\%) of the students partially relies on their computer to finish their home works, while only $(6 \%)$ of them depending on their computer to finish home works. Question 19 determined the existing of a special computer in labs, (50\%) of the students thinks their computer labs equipped with a special computer and the other (50\%) thinks reversely. The last question asked about the knowledge of students about IT, only $(21 \%)$ believe they have a good knowledge and experience of IT, while (79\%) think they don't have any experience and knowledge. 


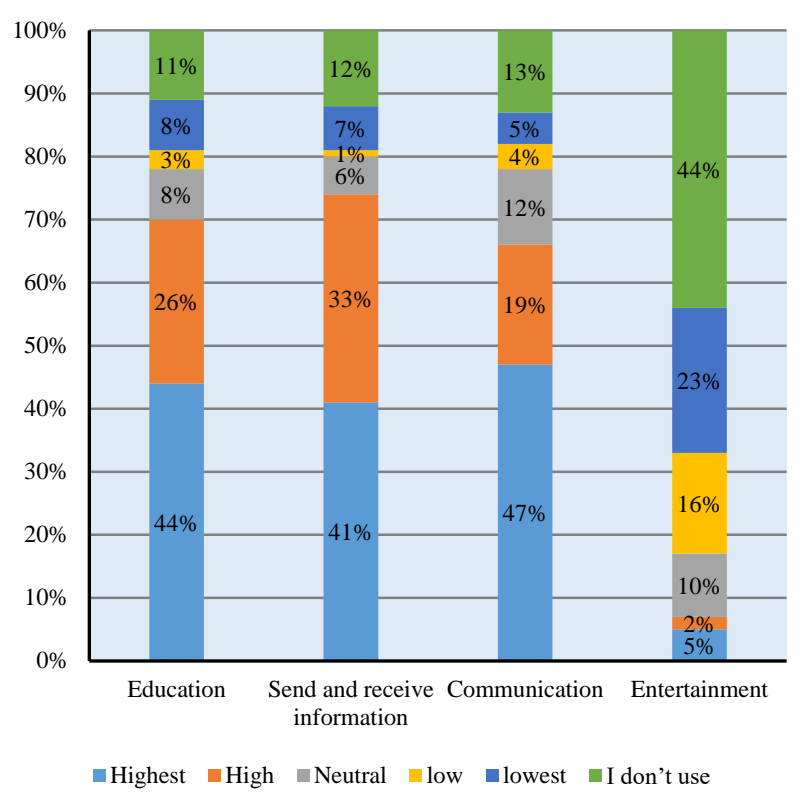

Fig. 2. For which purpose do you use an electronic device? (Instructors).

\section{Question about Information Technology for both Instructors and Students}

Fig. 2 provides information about the purposes of using electronic devices by instructors at the University of Sulaimani. (44\%) of the instructors highly use electronic devices for educational purposes, (41\%) for sending and receiving information, (47\%) for communication and only (5\%) for entertainments.

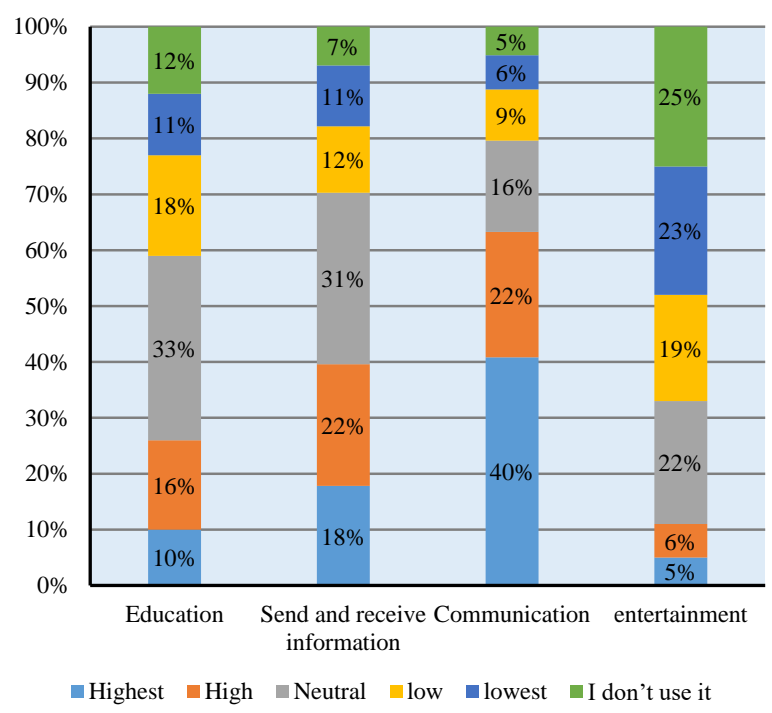

Fig. 3. For which purpose do you use an electronic device? (Students).

Fig. 3 provides information about the purposes used the electronic devices by students at the University of Sulaimani. $(10 \%)$ of the students highly use electronic devices for educational purposes, (18\%) for sending and receiving information, (40\%) for communication and only (5\%) for entertainments.

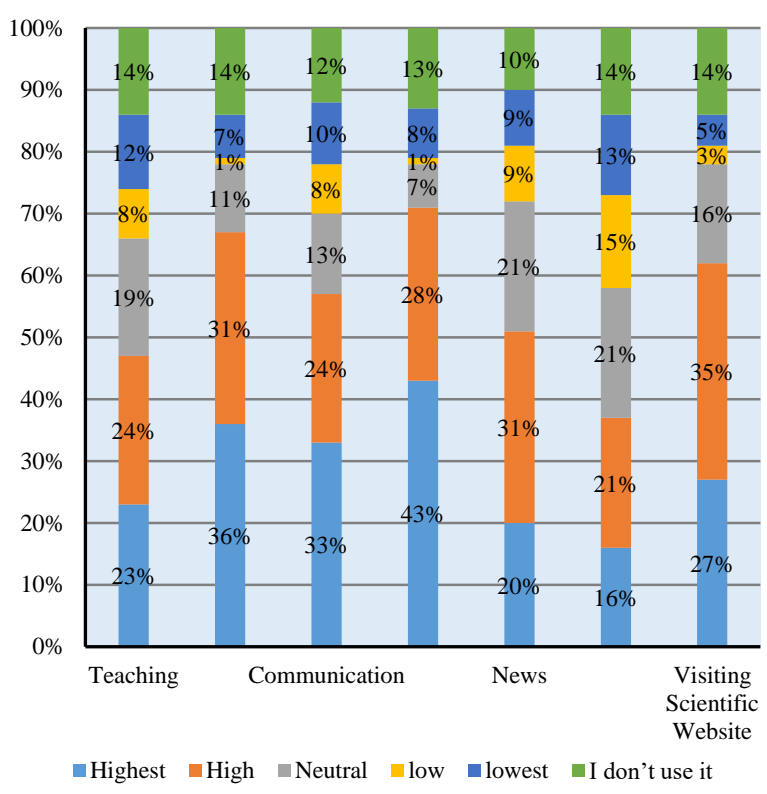

Fig. 4. For which purpose do you use the internet? (Instructors).

\section{Question About internet line for both Instructors and Students}

Fig. 4 shows a comparison of the purposes of using internet line by instructors. (23\%) of the instructors highly use internet line for teaching purposes, (36\%) for sending and receiving information (33\%) for all kind of communication, (43\%) for scientific researches and papers, (20\%) for getting news, (27\%) for visiting scientific websites and only (16\%) for visiting community websites.

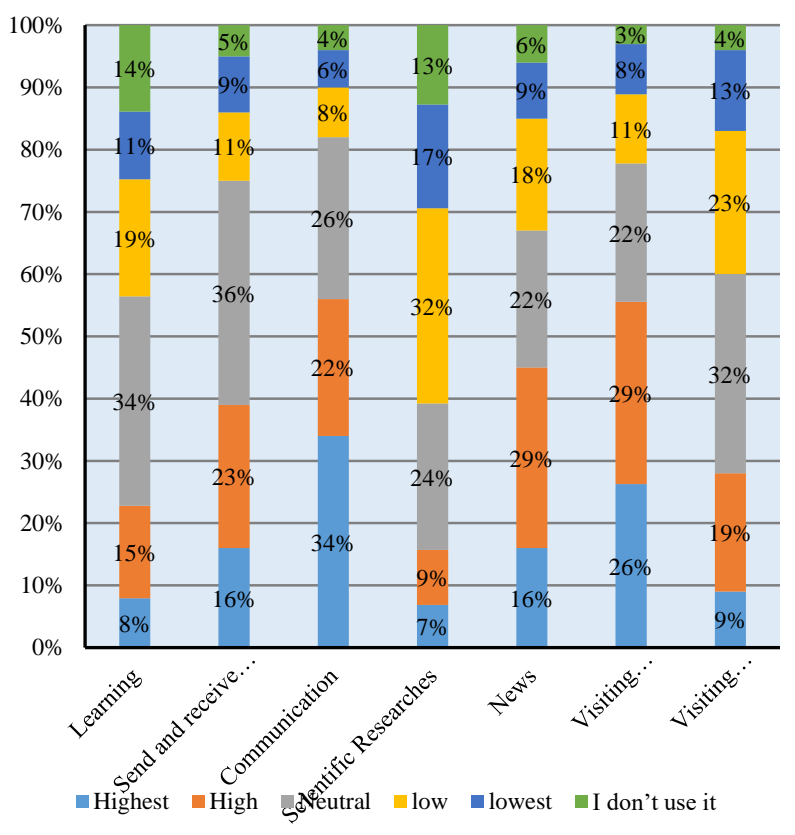

Fig. 5. For which purpose do you use the internet? (Students).

Fig. 5 shows a comparison of the purpose of using internet line by students. (8\%) of the instructors highly use internet line 
for learning purposes, (16\%) for sending and receiving information $(34 \%)$ for all kind of communication, $(7 \%)$ for scientific researches and papers, (16\%) for getting news, $(26 \%)$ for visiting community websites and only (9\%) for visiting scientific websites.

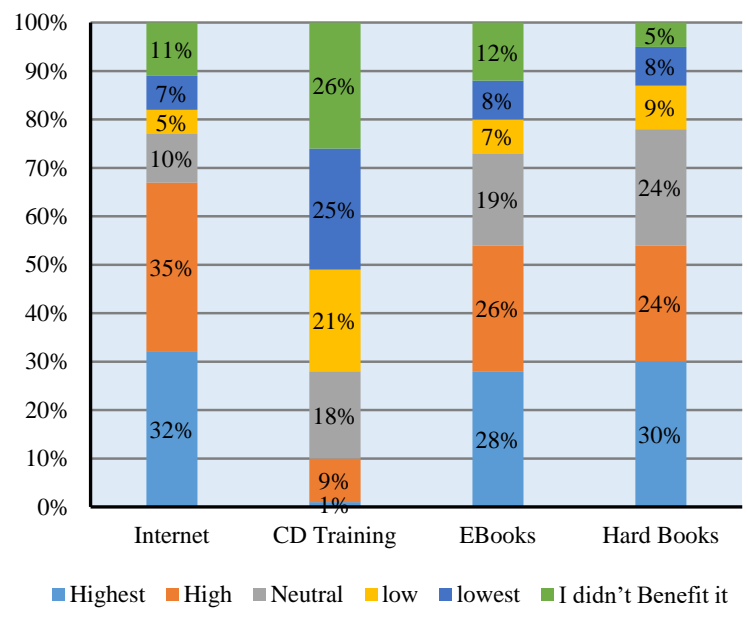

Fig. 6. Which of the sources have a benefit in education domain? (Instructors).

\section{E. Question About your College for both Instructors and Students}

Fig. 6 provides information about the kinds of sources that can benefit instructors in the purpose of the teaching process. (32\%) of the instructors highly benefits from all kind of internet resources, only $(1 \%)$ benefits from $\mathrm{CD}$ training materials, $(28 \%)$ from eBooks and $(30 \%)$ from a hard copy of books.

Fig. 7 provides information about the kinds of the sources that can benefit students in the purpose of learning process. $(13 \%)$ of the students highly benefits from all kind of internet resources, only (2\%) benefits from CD training materials, (3\%) from eBooks and (12\%) from a hard copy of books.

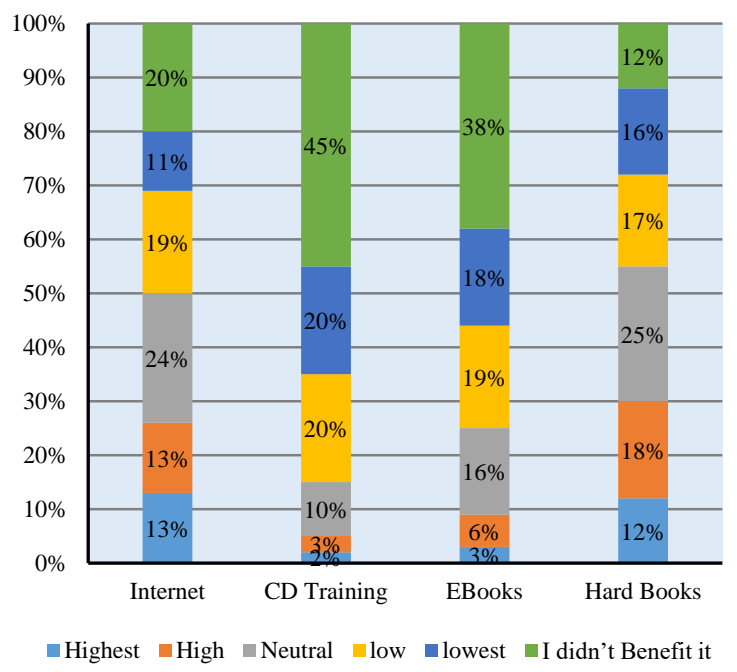

Fig. 7. Which of the sources have a benefit in education domain? (Students).

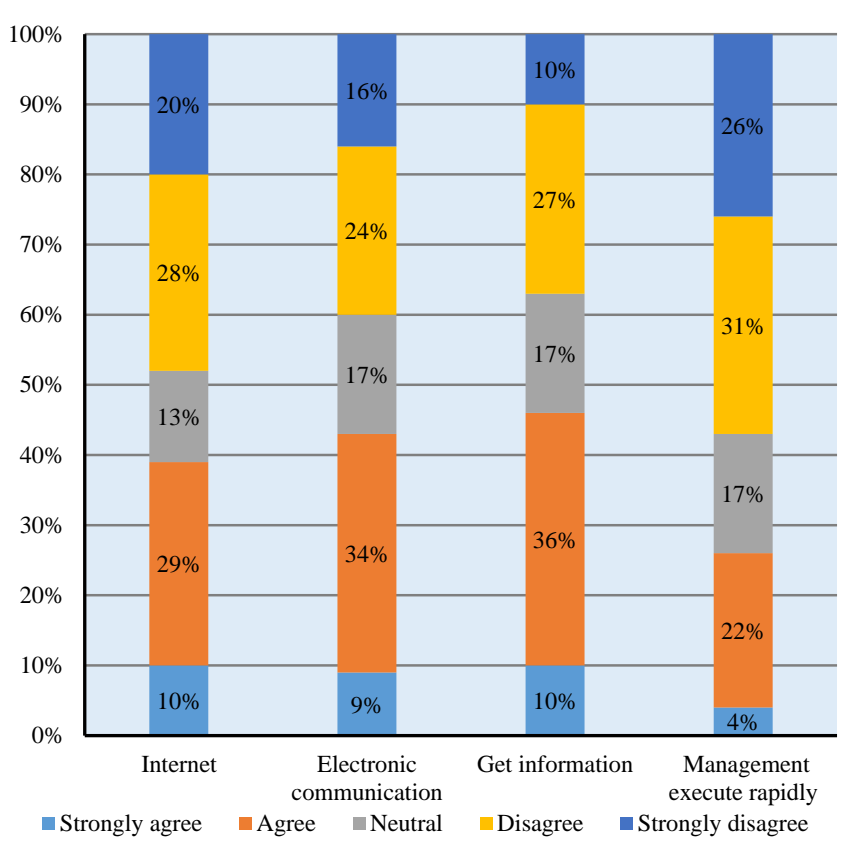

Fig. 8. In general, how do you evaluate your university from using information technology? (Instructors).

Fig. 8 shows the evaluation ratio of instructors' thought about the acceptance level of IT in the university daily works. $(10 \%)$ of the instructors strongly agreed on the internet services provided by the university, $(9 \%)$ of them strongly agreed on all kind of electronic communication, (10\%) on getting information from the university and (4\%) strongly agreed on the way of managing the university from IT perspective point.

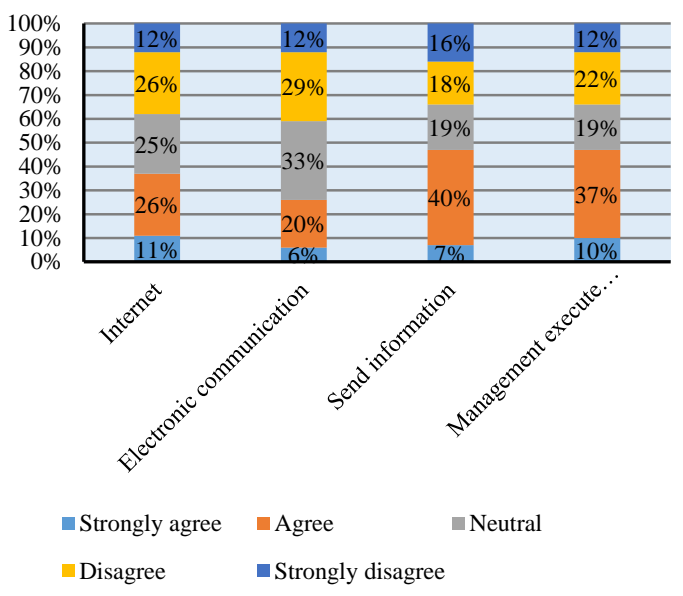

Fig. 9. In general, how do you evaluate your university from using information technology? (Students).

Fig. 9 shows the evaluation ratio of students' thought about the acceptance level of IT in the university daily works. (11\%) of the students strongly agreed on the internet services provided by the university, $(6 \%)$ of them strongly agreed on all kind of electronic communication, $(7 \%)$ on getting information from the university and (10\%) strongly agreed on the way of managing the university from IT perspective point. 


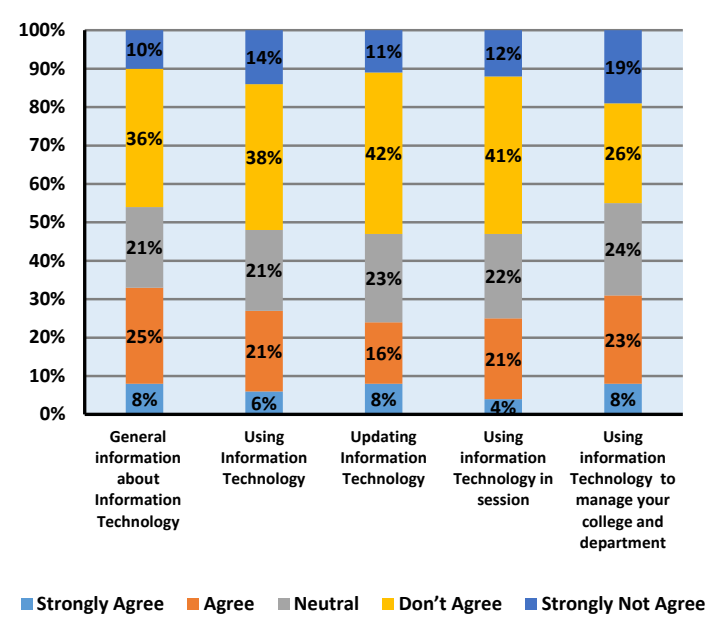

Fig. 10. Choose your opinion about your students. (Instructors).

Fig. 10 demonstrates information about the instructors' judgment for their students about how much they aware of IT. (8\%) only strongly agreed on that the students have a good knowledge about IT, (6\%) only strongly agreed that the students know how to use this knowledge, (8\%) thinks their students may update their IT knowledge continuously, (4\%) on using this knowledge for the benefit of their sessions and classes and $(8 \%)$ for managing works in their departments and colleges.

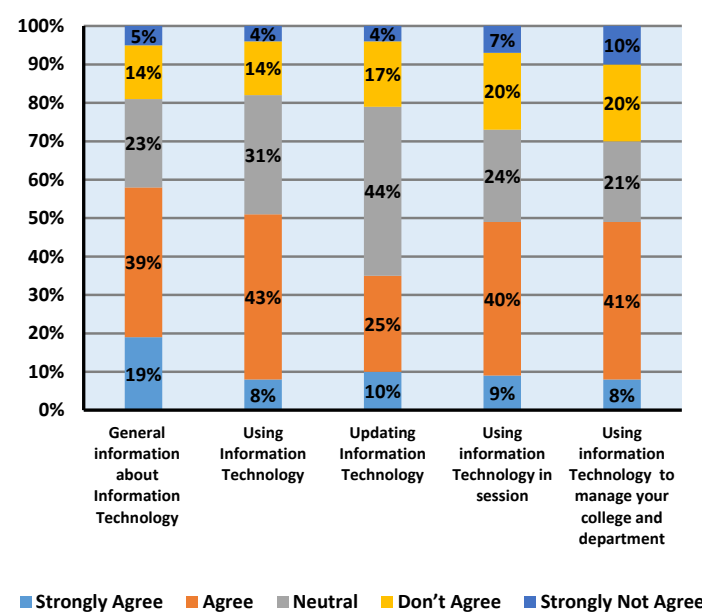

Fig. 11. Choose your opinion about your instructors. (Students).

Fig. 11 demonstrates information about the students' opinion for their instructors about how much they aware of IT. (19\%) of the students strongly agreed on that their instructors have a good knowledge about IT, (8\%) only strongly agreed that their instructors know how to use this knowledge, (10\%) thinks their instructors may update their IT knowledge continuously, $(8 \%)$ on using this knowledge for the benefit of their teaching sessions and (8\%) for managing works in their departments and colleges.

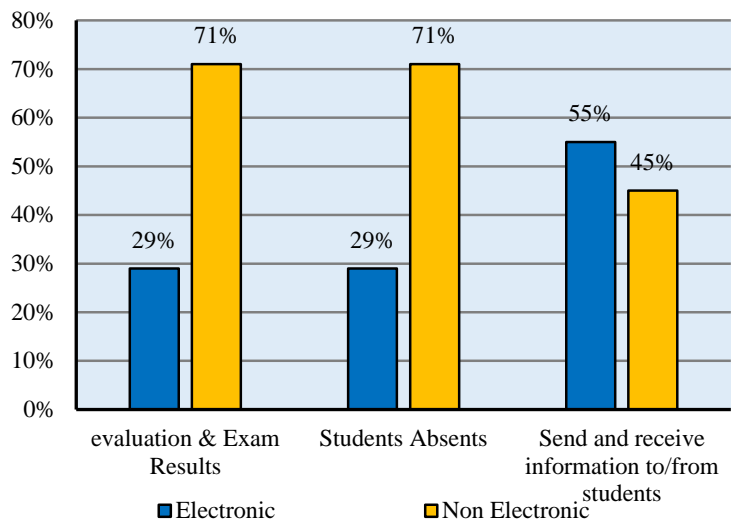

Fig. 12. For which form you use information technology? (Instructors).

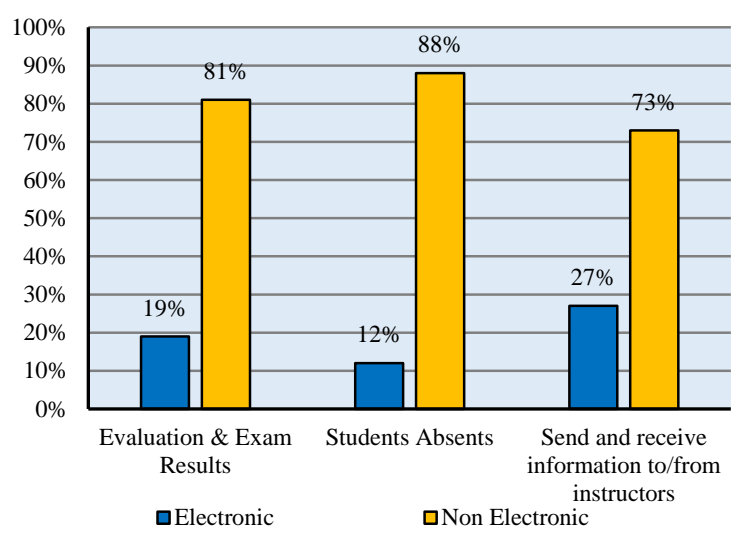

Fig. 13. For which form you use information technology? (Students).

Fig. 12 shows information about the electronic and nonelectronic ways which preferred by instructors. Most of the instructors preferred to used non-electronic way for publishing results for students exams, calculating absence of students and sending \& receiving information to/from students.

Fig. 13 shows information about the electronic and nonelectronic ways which preferred by students. Also, most of the students preferred to use non-electronic way for their instructors to publish results for their exams, calculating absence of them and sending \& receiving information to/from instructors.

\section{CONCLUSIONS}

- The majority of the lecturers in the University of Sulaimani are young-adult with assistant lecturer title, which, in general, they interact and use today technology easily in the benefit of their needs in the teaching process.

- Most of the lecturers are familiarized with windows desktop-based operating system. That is widely used in every science and academic field in Kurdistan region Iraq.

- Almost every lecturer can have access to the internet at home with a fair connection speed, which let them contribute more with other educational and scientific sites and institutes. 
- In general, the university and its colleges, and libraries provide poor electronic devices for teaching process and limited internet access.

- Most of the lecturers are aware and willing to use advanced information technology technique to serve the teaching process, even though the environment is not helping much.

- Most of the lecturers have an academic university profile. They use it to interact with students and with other lecturers, which give them an easy and costless way to present their course materials and ideas.

- Most of the lecturers use electronic devices equipped with internet line for education purposes in a way that some of them relies on it and think that it has become a need in education system. Even that, hard copy of books still has its own value.

- Most of the lecturers are satisfied with the electronic system exists in the University of Sulaimani.

- Most of the lecturers think that students have limited knowledge about information technology and the use of information technology in the education system.

- The University of Sulaimani provides limited range of access to information technology devices for students in the labs and libraries. This cause the students suffer from knowing and using existing technology used in their scientific fields and lead them think that technology are weak in the learning process and for that reason, they still rely on hard copy materials. Students use information technology skills in social media communication and some information transferring purposes. Thus, because students are unaware of the available technology provided by the University of Sulaimani, they think their university is poor in communication and management technology, but on the other hand, they think their lecturers have a good knowledge of how to use information technology in the education system.

\section{REFERENCES}

[1] Amiel, T., \& Reeves, T. C. (2008). Design-Based Research and Educational Technology: Rethinking Technology and the Research Agenda. Educational Technology \& Society, 11 (4), P. 26-36.

[2] Pritam Singh Negi, Vineeta Negi, Akhilesh Chandra, Impact of Information Technology on Learning, Teaching and Human Resource Management in Educational Sector, International Journal of Computer Science and Telecommunications [Volume 2, Issue 4, July 2011] P.6672.
[3] Franklin Wabwoba, Anselimo Peters Ikoha, Information Technology Research in Developing Nations: Major Research Methods and Publication Outlets, International Journal of Information and Communication Technology Research, Volume 1 No. 6, October 2011

[4] John P. Holdren, Thomas C. Power, Pedro I. Espina ,And Pedro I. Espina, The Networking And Information Technology Research And Development (Nitrd) Program 2012 Strategic Plan , Executive Office Of The President National Science And Technology Council Washington, D.C. 20502, July 1, 2012. P.

[5] Mohammad Esmail Ahmad, Ali Jalal Hussian, Monem A. Mohammed, Using Computer Techniques To Predict OPEC Oil Prices For Period 2000 To 2015 By Time-Series Methods, International Journal Of Scientific \& Technology Research Volume 5, Issue 06, June 2016 Issn 2277-8616. P. 2.

[6] R.Revarthy, Role of ICT in Providing Quality Education.

[7] Radwan Ali, Irvin R. Katz, Information And Communication Technology Literacy: What Do Businesses Expect And What Do Business Schools Teach? Educational Testing Service, ETS RR-10-17, August 2010

[8] Felix Kayode OLAKULEHIN, INFORMATION AND COMMUNICATION TECHNOLOGIES IN TEACHER TRAINING AND PROFESSIONAL DEVELOPMENT IN NIGERIA, Turkish Online Journal of Distance Education-TOJDE January 2007 ISSN 13026488, Volume: 8 Number: 1 Article: 11, P.137-138

[9] Craig Furneaux, How does Information Technology impact the methods, potential and purpose of education?, ETL Conference, 2004, Logan Campus, Griffith University, P.3-4

[10] S.P. Rajguru, ROLE OF ICT IN PROVIDING QUALITY EDUCATION, Directory of Research Journals Researchbib, Vol 3 Issue 11 May 2016, P.1.

[11] Yahia H., Talibe S, Introduction to Computer Science and Problem Solving, Dar Wael, Amman-Jordan, First Edition, 2001, P. 30-31.

[12] Vladimir Kinelev, Piet Kommers, Boris Kotsik, Information and Communication Technologies in Secondary Education. Position Paper, UNESCO Institute For Information Technologies In Education (IITE), Printed In The Russian Federation, 2004, P.11.

[13] Gorana Celebic, Dario Ilija Rendulic, Basic Concepts of Information and Communication Technology, Handbook, Itdesk.Info - Project of Compter E-Education with Open Access, Zagreb, 2011, P.17.

[14] Syed Noor-Ul-Amin, An Effective use of ICT for Education and Learning by Drawing on Worldwide Knowledge, Research, and Experience:ICT as a Change Agent for Education, Scholarly Journal of Education Vol. 2(4), 2013, P.38-39-40.

[15] SeánGallagher, ICT in Education: Policy, pedagogy and practice, INTo education conference Letterkenny 2017, P.9.

[16] Giselle Martins dos Santos Ferreira and Rafael Guilherme Mourão Castiglione, ICT in Education: personal learning environments in perspectives and practices of young people, http://dx.doi.org/10.1590/S1678-4634201702153673, Educ. Pesqui., São Paulo, v. 44, e153673, 2018, P.17.

[17] Noor Agha, B.S. Ghanghas* and P.K. Chahal, Use of Information and Communication Technologies by Extension Personnel to Disseminate Agricultural Information, International Journal of Current Microbiology and Applied Sciences,, Volume 7 Number 04 (2018), P.1370. 